\title{
Kapasitas Pengolah Ubi Kayu "Enbal" dan Pengaruhnya terhadap Keberlanjutan Usaha di Maluku Tenggara
}

\section{Capacity of Cassava Processor "Enbal" and its Effect on Home Industry Sustainability at Southeast Maluku}

\author{
Welem Buce Leasa ${ }^{1}$, Siti Amanah ${ }^{2}$, Anna Fatchiya ${ }^{2}$ \\ ${ }^{1}$ Dinas Pertanian Kabupaten Maluku Tenggara \\ ${ }^{2}$ Departemen Sains Komunikasi dan Pengembangan Masyarakat, Fakultas Ekologi Manusia \\ Institut Pertanian Bogor, Bogor
}

\begin{abstract}
"Enbal" (Manihot esculenta Crantz) is a type of cassava that contains poison cyanide acid (HCN) around 96 ppm. Rural people of Southeast Maluku District are able to process enbal to become various local food, but they have not been able to develop their business properly. This study aimed to analyze the level of enbal processor capacity, to analyze the factors affecting the enbal processor capacity, and to analyze the effects of capacity on the sustainability of enbal processing business. The results showed that the level of enbal processor is still limited in market strategy and access to bussines capital, but technical processing has become better. The level of enbal processor is positively and directly influenced by internal and external factors. The internal characteristics are group activeness and business development motivation, while the external dominant factors are market support as price conformity, availability of information, product demand, place of sale and availability of business facilities such as bussines capital and group support as learning place, and extension education support consisting of suitability of extension materials, method and competent agent of change. The capacity of enbal processor as technical processing, market strategy and access to bussines capital positively and directly affects the sustainability of the anbal processing business.
\end{abstract}

Keywords: capacity, home industries, traditional food, cassava, Maluku

\begin{abstract}
Abstrak
“Enbal” (Manihot esculenta Crantz) merupakan salah satu jenis Ubi Kayu yang memiliki asam sianida (HCN) yang tinggi (>96 ppm). Saat ini masyarakat Maluku Tenggara telah mampu mengolah "enbal” menjadi aneka produk yang dapat dipasarkan. Usaha pengolahan enbal akan berkembang lebih baik apabila pengolah enbal memiliki kapasitas yang memadai. Penelitian ini bertujuan untuk menganalisis tingkat kapasitas pengolah enbal, menganalisis faktor-faktor yang mempengaruhi kapasitas pengolah enbal, dan menganalisis pengaruh kapasitas terhadap keberlanjutan usaha pengolahan enbal di Kabupaten Maluku Tenggara. Hasil penelitian menunjukkan bahwa tingkat kapasitas pengolah enbal masih terbatas dalam aspek strategi pasar dan akses modal usaha tetapi teknis pengolahan telah dilakukan dengan lebih baik. Tingkat kapasitas pengolah enbal dipengaruhi secara positif langsung oleh faktor internal dan eksternal. Karakteristik internal terdiri atas keaktifan dalam kelompok dan motivasi mengembangkan usaha sedangkan faktor eksternal yang dominan berpengaruh adalah dukungan pasar yang terdiri atas kesesuaian harga, ketersediaan informasi, permintaan produk, dan tempat penjualan kemudian diikuti oleh faktor ketersediaan fasilitas usaha berupa ketersediaan modal, dukungan kelompok sebagai wadah belajar dan fasilitasi usaha, dan dukungan penyuluhan yang terdiri atas kesesuaian materi, ketepatan metode dan kompetensi penyuluh. Kapasitas pengolah enbal berupa teknis pengolahan, strategi pasar dan akses modal usaha berpengaruh positif langsung terhadap keberlanjutan usaha pengolahan enbal.
\end{abstract}

Kata kunci: kapasitas, keberlanjutan usaha, pangan lokal, Maluku

Pendahuluan

Ubi kayu pahit "enbal" (Manihot esculenta Crantz) merupakan pangan lokal masyarakat Maluku Tenggara yang memiliki kandungan asam sianida lebih dari 96 ppm (Hartati 2016). Pengolahan "enbal" telah dilakukan secara turun temurun dengan cara dan peralatan yang sederhana dan hingga saat ini telah dihasilkan aneka produk yang dapat dipasarkan seperti enbal bunga, gula kacang, keju mentega (Riry et al.,
2013).

Usaha pengolahan enbal akan berkembang bila pengolah enbal memiliki kapasitas yang memadai dalam menjalankan usaha. Peningkatan kapasitas pengolah enbal akan sangat membantu dalam proses pengolahan sehingga dapat menghasilkan produk yang sehat dan aman. Milen (2001) menyatakan kapasitas adalah kemampuan individu, organisasi atau sistem dalam melaksanakan fungsinya secara efektif, efisien, dan berkelanjutan. Menurut UNDP (1998) kapasitas

\footnotetext{
${ }^{1}$ Korespondensi penulis

E-mail: welembuce@gmail.com
} 
seseorang dapat dikembangkan melalui proses terus menerus hingga memiliki kemampuan yang diinginkan. Liou (2004) menyatakan bahwa pengembangan kapasitas akan membantu individu untuk memiliki kemampuan sehingga dapat memanfaatkan potensi yang dimiliki secara maksimal. Kapasitas pengolah enbal adalah kemampuan pengolah dalam aspek teknis pengolahan, strategi pasar, dan askes modal untuk mengembangkan usaha pengolahan enbal secara berkelanjutan.

Terdapat beberapa kendala yang dihadapi pengolah dalam menjalankan usaha pengolahan enbal. Kendala-kendala tersebut terkait dengan kemampuan menyediakan dan mengakses modal usaha pada lembaga keuangan, kemampuan memasarkan produk (Fausiah, 2016), dukungan kelompok (Indariawati et al., 2011). Penyuluhan yang diberikan saat ini bagi pengolah enbal perlu diarahkan pada aspek teknis pengolahan, strategi pasar, dan akses modal. Penyampaian materi yang sesuai dan penerapan metode penyuluhan yang tepat akan membantu keberlanjutan usaha pengolahan enbal.

Kata "keberlanjutan" yang saat ini digunakan secara meluas dalam lingkup program pembangunan memiliki arti menjaga agar suatu upaya terus berlangsung, kemampuan untuk bertahan dan menjaga agar tidak merosot. Dalam konteks pertanian, keberlanjutan pada dasarnya adalah kemampuan untuk tetap produktif sekaligus tetap mempertahankan basis sumber daya. Secara luas pertanian dikatakan berkelanjutan jika mantap secara ekologis, berlanjut secara ekonomi, adil, manusiawi, dan luwes (Reijntjes, 1999).

Kriteria dan indikator keberlanjutan mencakup aspek profit (ekonomi), people (sosial), dan planet (lingkungan) (Wibowo, 2005 dikutip Hadad dan Maftuchah, 2015). Keberlanjutan ekonomi, ekologi maupun sosial suatu usaha penting diketahui untuk kepentingan pengembangan usaha (Ibrahim et al., 2013, Hikmah et al., 2011). Keberlanjutan usaha pengolahan enbal adalah kemampuan untuk menjaga agar usaha pengolahan enbal tetap terus berlangsung dari aspek produksi, omset, dan keuntungan usaha (ekonomi).

Tujuan penelitian ini adalah: (1) menganalisis tingkat kapasitas pengolah enbal di Kabupaten Maluku Tenggara, (2) menganalisis faktor-faktor yang berpengaruh tehadap kapasitas pengolah enbal, (3) menganalisis pengaruh kapasitas pengolah enbal terhadap keberlanjutan usaha pengolahan enbal di Kabupaten Maluku Tenggara.

\section{Metode Penelitian}

Penelitian ini menggunakan pendekatan kuantitatif dan diperkaya dengan analisis kualitatif. Survei dilakukan untuk memperoleh data primer menggunakan kuesioner. Lokasi penelitian berada pada empat kecamatan di Kabupaten Maluku Tenggara yaitu Kecamatan Kei Kecil, Kei Kecil Timur, Manyew, dan Hoat Sorbay. Populasi penelitian adalah pengolah enbal pada sembilan kelompok pengolahan berjumlah 107 orang yang semuanya adalah wanita. Jumlah sampel ditetapkan dengan rumus Slovin sebanyak 84 orang, kemudian jumlah sampel pada masingmasing kelompok ditentukan menggunakan teknik proportional random sampling.

Peubah dalam penelitian ini adalah karakteristik internal (X1), dukungan kelompok (X2), dukungan penyuluhan (X3), ketersediaan fasilitas usaha (X4), dukungan pasar (X5) kapasitas pengolah enbal (Y1) dan keberlanjutan usaha pengolahan enbal (Y2). Pengambilan data lapangan pada bulan Maret-April 2017. Analisis data kuantitatif menggunakan Partial Least Square (PLS) dengan aplikasi SmartPLS3. Model yang dihasilkan berupa model pengukuran dan model struktural. Model pengukuran (outer model) dihasilkan untuk menilai validitas konstruk dan reliabilitas dari variabel manifest/indikator melalui proses iterasi algoritma untuk mendapatkan parameter model pengukuran.

Validitas konstruk terdiri dari validitas konvergen dan diskriminan. Parameter validitas konvergen yang dinilai adalah faktor loading $>0.7$ (outer loadings), Average Variance Extracted (AVE) $>0.5$. Parameter validitas diskriminan adalah akar AVE $>$ korelasi variabel laten (discriminant validity). Reliabilitas dinilai berdasarkan nilai composite reliability yaitu $>0.7$.

Model struktural (inner model) dihasilkan untuk menilai kekuatan estimasi antar variabel laten/ konstruk melalui proses bootstraping, dievaluasi menggunakan nilai $\mathrm{R}^{2}$ untuk mengukur tingkat variasi perubahan variabel independen terhadap variabel dependen. Semakin tinggi nilai $\mathrm{R}^{2}$ semakin baik model prediksi dari model penelitian yang diajukan. Pengujian hipotesis satu arah (one tailed) dilakukan dengan melihat tingkat signifikansi dari nilai koefisien path yang ditunjukkan oleh nilai t-statistik diatas 1,64 untuk alpha 5 persen. Nilai $\mathrm{R}^{2} 0.75,0.50$, dan 0.25 dapat disimpulkan bahwa model kuat, moderat, dan lemah. 


\section{Hasil dan Pembahasan}

\section{Karakteristik Internal Pengolah Enbal}

Karakteristik internal pengolah enbal menunjukkan bahwa umur pengolah berada pada pertengahan kedewasaan, pendidikan formal, pendidikan non formal, pengalaman berusaha, dan motivasi mengembangkan usaha berada pada kategori rendah, rata-rata tidak memiliki mesin pengolahan, dan jumlah bahan baku yang digunakan sedikit tetapi keaktifan dalam kelompok berada pada kategori tinggi (Tabel 1).

\section{Umur}

Pengolah enbal di Kabupaten Maluku Tenggara rata-rata berada pada umur 46 tahun. Pengolahan enbal sangat terkait dengan umur pengolah karena enbal merupakan pangan lokal yang telah diolah sejak lama baik untuk konsumsi maupun untuk dijual. Hal tersebut dapat dicermati dari pernyataan $\mathrm{MN}$, seorang bendahara kelompok pengolahan sebagai berikut:

\section{"kelompok baru jalan 2013 tapi kalau mama- mama yang su umur kaya berapa orang di sini dong su buat dari dolo, orang asli sini to. Masih muda-muda lai dong su jual enbal".}

Menurut Havighurst (1974) pengolah enbal yang berada pada usia pertengahan kedewasaan memiliki fisik yang kuat sehingga dapat melaksanakan setiap tahapan pekerjaan dalam pengolahan enbal. Tahapan dalam pengolahan enbal secara umum terdiri atas empat tahap yaitu penyiapan bahan baku (enbal gepe), penyiapan enbal halus, pengolahan, pengemasan dan pemasaran produk. Pada tahap penyiapan bahan baku umbi enbal yang telah dipanen dikupas, dibersihkan dan dihaluskan menggunakan mesin parut selanjutnya hasil parutan kemudian dipres/digepe untuk mengeluarkan air enbal yang mengandung asam sianida.

Proses selanjutnya adalah setelah kering, enbal gepe diparut sehingga halus agar dapat digunakan pada proses pengolahan. Pada proses pengolahan enbal halus diletakan pada cetakan untuk diproses baik melalui pembakaran maupun penggorengan. Penggunaan cetakan sangat bergantung pada jenis produk yang akan dihasilkan. Hasil penelitian ini sejalan dengan Delima et al., (2016) yang menyatakan bahwa umur produktif sangat membantu pengolah pangan rumah tangga bekerja meraih kesuksesan usaha karena tidak terkendala masalah fisik.

\section{Pendidikan Formal}

Pendidikan formal yang dapat diselesaikan oleh pengolah enbal rata-rata adalah pada jenjang sekolah menengah pertama dengan lama mengikuti pendidikan adalah 9 tahun. Kondisi tersebut disebabkan pada masa lalu akses ke kota kecamatan atau kabupaten untuk menjangkau fasilitas pendidikan menengah/ tinggi yang tersedia masih sulit karena terbatasnya transportasi bahkan ada yang menempuh perjalanan dengan berjalan kaki. Rata-rata jarak tempuh masingmasing lokasi ke kota kecamatan dan kabupaten adalah 12 dan $15 \mathrm{~km}$ sehingga banyak pengolah enbal yang tidak melanjutkan pendidikan ke jenjang yang lebih tinggi karena terbatasnya sarana dan prasarana. Hal tersebut dapat dicermati dari ungkapan BJ, anggota salah satu kelompok pengolahan sebagai berikut:

"dulu hidup kami susah, sekolah juga jauh
kalau mau turun sekolah di kotakamibiasanya
jalan kaki, mobil len juga tidak banyak jadi
kami tidak sekolah lebih tinggi, tidak sama
skarang semua ada"

\section{Pendidikan Non Formal}

Pelatihan yang diikuti pengolah enbal ratarata sebanyak dua kali. Pelatihan yang diikuti terkait dengan pembuatan enbal gula kacang, dodol kasbi, enbal kalsium, enbal krispi, enbal ikan sayur (ekansa), tepung mocaf dan olahannya serta beberapa produk lain seperti keripik dan selai pisang. Pengolah enbal mengikuti pelatihan yang diselenggarakan oleh beberapa pihak seperti dinas ketahanan pangan, dinas perindustrian dan perdagangan, politeknik perikanan negeri dan lembaga ilmu pengetahuan indonesia. Pengolah enbal yang mengikuti kegiatan pelatihan memiliki pengetahuan dan keterampilan baru dalam mengolah enbal, seperti awalnya mereka tidak mengetahui cara membuat tepung mocaf dan olahannya setelah mengikuti pelatihan yang diselenggarakan oleh LIPI kini mereka telah mampu melakukannya sendiri. Hal tersebut sejalan dengan Muhibudin et al., (2015) yang menyatakan bahwa salah satu cara meningkatkan kemampuan pengusaha hasil pertanian adalah dengan mengikuti pelatihan. 
Tabel 1. Karakteristik Internal Pengolah Enbal di Kabupaten Maluku Tenggara Tahun 2017

\begin{tabular}{|c|c|c|c|c|}
\hline No & Karakteristik Internal & Kategori & Jumlah (Org) & Persen (\%) \\
\hline \multirow[t]{3}{*}{1} & \multirow[t]{3}{*}{$\begin{array}{l}\text { Umur (Tahun) } \\
\text { Rataan }=46\end{array}$} & $\begin{array}{l}\text { Dewasa awal } \\
(18-30)\end{array}$ & 7 & 8,3 \\
\hline & & $\begin{array}{l}\text { Pertengahan kedewasaan } \\
(31-60)\end{array}$ & 45 & 53,6 \\
\hline & & $\begin{array}{l}\text { Kematangan akhir } \\
(>60)\end{array}$ & 10 & 11,9 \\
\hline \multirow[t]{2}{*}{2} & \multirow{2}{*}{$\begin{array}{l}\text { Pendidikan formal (Tahun) } \\
\text { Rataan }=9\end{array}$} & Rendah $(4-10)$ & 53 & 63,1 \\
\hline & & Tinggi $(11-16)$ & 31 & 36,9 \\
\hline \multirow[t]{2}{*}{3} & \multirow{2}{*}{$\begin{array}{l}\text { Pendidikan non formal } \\
\text { (Kali) Rataan=2 }\end{array}$} & Rendah $(0-7)$ & 80 & 95,2 \\
\hline & & Tinggi $(8-15)$ & 4 & 4,8 \\
\hline \multirow[t]{2}{*}{4} & \multirow{2}{*}{$\begin{array}{l}\text { Pengalaman berusaha } \\
\text { (Tahun) Rataan }=16\end{array}$} & Rendah $(5-17)$ & 51 & 60,7 \\
\hline & & Tinggi $(18-30)$ & 33 & 39,3 \\
\hline \multirow[t]{2}{*}{5} & \multirow{2}{*}{$\begin{array}{l}\text { Keaktifan dalam kelompok } \\
\text { (Skor) }\end{array}$} & Rendah $(2-4)$ & 37 & 44,0 \\
\hline & & Tinggi $(5-7)$ & 47 & 56,0 \\
\hline \multirow[t]{2}{*}{6} & \multirow[t]{2}{*}{ Motivasi berusaha (Skor) } & Rendah $(1-2)$ & 74 & 86,9 \\
\hline & & Tinggi $(3-4)$ & 11 & 13,1 \\
\hline \multirow[t]{2}{*}{7} & \multirow{2}{*}{$\begin{array}{l}\text { Kepemilikan mesin (Unit) } \\
\text { Rataan }=0\end{array}$} & Tidak Memiliki (0) & 53 & 63,1 \\
\hline & & Memiliki (1-2) & 31 & 36,9 \\
\hline \multirow[t]{2}{*}{8} & \multirow{2}{*}{$\begin{array}{l}\text { Jumlah bahan baku } \\
\text { (bungkus) Rataan= } 20\end{array}$} & Sedikit $(\leq 45)$ & 62 & 73,8 \\
\hline & & Banyak $(\geq 46)$ & 22 & 26,2 \\
\hline
\end{tabular}

\section{Pengalaman Berusaha}

Pengalaman pengolah enbal dalam berusaha rata-rata adalah 16 tahun. Lama berusaha sangat terkait dengan umur pengolah karena sebagai pangan lokal, enbal telah diolah secara turun temurun. Hal tersebut menyebabkan pengolah yang berumur tua lebih lama mengolah enbal dengan pengetahuan dan keterampilan lebih baik dibandingkan yang berumur muda. Pengolah enbal yang memiliki pengalaman lebih banyak biasanya mengarahkan anggota kelompok pada saat kerja bersama dalam kelompok. Hal tersebut dapat dicermati dari ungkapan $\mathrm{MN}$, salah satu ketua kelompok pengolahan sebagai berikut:

"ibu-ibu ini dong kerja memang kadangkadang ya sembrono saja ikut dong pung mau, padahal kan seharusnya katong kerja kalau katong mau dapat hasil yang bagus kan musti ikut. Umpamamnya kan saya punya pengalaman sudah banyak kalo cara bikin enbal yang bagus itu bagaimana, dong seng bisa datang atur ikut dong pung mau lalu katong ini mau buat enbal dari enbal gepe yang berapa hari, oh seng bisa".

Hasil penelitian ini sejalan dengan Sapar et al., (2006) yang menyatakan bahwa lama berusaha akan memberikan proses pendidikan yang cukup memadai untuk menjalankan usaha.

\section{Keaktifan dalam Kelompok}

Kehadiran dan keaktifan pengolah enbal yang tinggi dalam kegiatan kelompok merupakan wujud dari komitmen mereka terhadap jadwal kerja yang telah disepakati bersama. Kegiatan yang dilakukan oleh kelompok terdiri dari kegiatan pengolahan dan pertemuan. Kegiatan pengolahan dilakukan agar pengolah enbal dapat belajar bersama dengan cara mempraktekan jenis olahan enbal yang belum diketahui. Terkait hal tersebut maka setiap anggota kelompok yang hadir pada kegiatan pengolahan akan diberikan tugas sesuai tahapan pekerjaan dalam pengolahan enbal sehingga semua memiliki kesempatan untuk belajar dan aktif dalam kegiatan kelompok. Hal tersebut dapat 
dicermati dari ungkapan $\mathrm{DO}$ dan $\mathrm{MN}$, sekretaris dan ketua salah satu kelompok pengolahan sebagai berikut:

"kami semua akan berusaha untuk hadir dalam kegiatan kelompok kecuali kami sakit atau tidak berada di tempat karena keperluan di luar kampung".

"jadi waktu dong datang katong pembagian kerja macam satu ayak, satu bagian di kompor untuk bakar, satu di bagian panggang. Karena katong panggang atau jemur itu seng bisa taruh bagitu saja, musti taru berapa menit bagitu datang balik lagi sampai kering, kalau umpamanya katong seng balik-balik berarti nanti bengkok, jadi lihat saja kalau ujung sudah mulai melengkung balik lagi supaya rata. Kalau seng balik-balik berarti katong disini punya istilah jadi enbal menari”.

Hal tersebut sejalan dengan Wibowo et al., (2012) yang menemukan bahwa anggota yang aktif pada kegiatan kelompok meningkat kemampuannya dalam menjalankan usaha.

\section{Motivasi Mengembangkan Usaha}

Motivasi pengolah enbal dalam mengembangkan usaha berada pada kategori rendah terlihat dari keinginan menambah jenis dan jumlah olahan hanya sebanyak 1-2 kali dari yang biasanya dihasilkan. Hal tersebut karena pengolah bekerja sendiri dan masih ragu akan pemasarannya terutama jenis enbal aneka rasa karena mudah rusak. Namun, jika ada pelanggan yang memesan akan tetap dipenuhi sesuai jumlah pesanan. Hal tersebut dapat dicermati dari ungkapan DO, salah seorang sekretaris kelompok pengolahan sebagai berikut:

“jadi skarang katong kerja berdasarkan pesanan. Kalau orang pesan banyak katong bikin banyak ne kalau anggota bikin tiaptiap bikin dia punya jadi kalau ada yang mau bikin banyak kasi tinggal saja ne orang su tau jadi nanti dong beli di rumah saja, katong bikin bagini kaget tinggal la orang seng beli bagimana, yang penting katong pung inovasi baru katong cari saja bikin apa-apa la kalau orang pesan baru katong bikin".

Menurut Pakpahan et al., (2006) bahwa permintaan pasardanpeluangmendapatkankeuntungan mampu mendorong nelayan mengembangkan usaha penangkapan ikan.

\section{Kepemilihan Mesin Pengolahan}

Kepemilikan mesin pengolahan terbatas karena rata-rata pengolah tidak memiliki mesin, hanya $36,9 \%$ yang memiliki 1-2 unit. Jenis yang dimiliki adalah mesin parut enbal dan peniris minyak untuk produk stik enbal. Mesin parut sangat penting dalam proses pengolahan terutama untuk menghaluskan umbi enbal pada saat penyiapan bahan baku dan enbal halus untuk persiapan pengolahan karena lebih cepat prosesnya sehingga menghemat waktu dan tidak menguras tenaga dibandingkan jika umbi enbal diparut secara manual menggunakan parutan tradisional. Apabila pengolah enbal tidak memiliki mesin parut sendiri maka dapat menggunakan mesin kelompok atau sewa pada orang yang menyewakan mesinnya. Hal tersebut dapat dicermati dari ungkapan EO, salah seorang ketua kelompok pengolahan sebagai berikut:

"kalau barang lain katong masih bisa beli macam kompor, loyang, nyiru,cetakan tapi kalau macam mesin parut kan harga di atas satu juta jadi katong susah juga. Kalau kelompok pu ada syukur tapi kalau seng biasanya katong sewa di orang yang punya, satu ember boyo lima ribu rupiah".

\section{Jumlah Bahan Baku}

Rata-rata pengolah enbal menggunakan 20 bungkus enbal gepe dalam sebulan. Jumlah enbal gepe yang digunakan bergantung pada keaktifan dan jenis produk yang dihasilkan. Aktif tidaknya pengolah enbal dalam berproduksi tergantung pada permintaan produk baik melalui penjualan langsung maupun pemesanan. Permintaan produk mudah dipenuhi pengolah karena enbal gepe tersedia dan mudah diperoleh karena umumnya pengolah enbal memiliki kebun sendiri juga banyak yang menjual di pasar. Hal tersebut dapat dicermati dari ungkapan $\mathrm{MN}$ sebagai berikut:

"katong punya enbal banyak di kebun, berdiri saja di kebun karena seng bisa pi gale to kalau kesempatan gale itu gale banya-banya datang bakar biar perlu buat tabal-tabal. Kalau beli kan buat tabal skali katong perhitungan tapi kalau kebun sendiri katong buat saja. Semakin 
tebal kan orang semakin suka”.

Hal tersebut sejalan dengan Miftakhuljanah et al., (2016) yang menyatakan bahwa keputusan perempuan menjalankan usaha rumah tangga karena didukung oleh ketersediaan bahan baku.

\section{Dukungan Kelompok dalam Meningkatkan Kapasitas Pengolah Enbal}

Dukungan kelompok sebagai wadah belajar dan fasilitasi usaha berada pada kategori tinggi (Tabel 2).

\section{Wadah Belajar}

Pengolah enbal menyatakan setelah menjadi anggota kelompok mereka mendapat pengetahuan dan keterampilan baru tentang pengolahan enbal, mengikuti bermacam kegiatan belajar, dan belajar menyampaikan pendapat dengan baik dibandingkan sebelum menjadi anggota kelompok.

Terdapat tiga sumber belajar utama pengolah enbal di dalam kelompok yaitu pengolah enbal belajar dari anggota kelompok yang ditugaskan mengikuti kegiatan di luar kelompok seperti pelatihan, instansi pemerintah yang langsung ke kelompok, dan anggota yang menemukan cara baru. Hal tersebut dapat dicermati dari ungkapkan DO, seorang sekretaris kelompok pengolahan sebagai berikut:

"katong kerja itu biasa sama-sama semua, ada yang bikin makanan par katong makan, ada yang ayak, bakar, kikis, jemur, jadi semua tau. Keuntungan kelompok itu bagitu, kalau katong sendiri di katong pung rumah katong seng tau bikin apa-apa, batas yang katong tau saja. Tapi kalau berkelompok bisa bagi pengalaman, umpama ini dia tau ini bisa ajar untuk yang lain ikut. Kalau sendiri-sendiri itu sapa mau kasi tau. Katong pung produk juga karena kelompok jadi bisa laku”.

Pengolah enbal yang ditugaskan untuk mengikuti kegiatan belajar di luar kelompok setelah selesai dan kembali harus mengajarkan apa yang diperoleh kepada seluruh anggota kelompok pada saat jadwal kerja kelompok. Selain itu, instansi pemerintah daerah yang menjadi sumber belajar pengolah enbal seperti dinas ketahanan pangan. Mereka biasanya berkunjung ke kelompok-kelompok pengolahan untuk mempraktekan resep/cara baru dalam mengolah enbal. Sumber belajar ketiga adalah pengolah enbal yang karena sering mencoba kemudian menemukan cara baru dan diajarkan kepada seluruh anggota kelompok. Hal tersebut sejalan dengan Anantanyu (2011) yang menyatakan bahwa kelompok sebagai sumber belajar dapat meningkatkan kemampuan anggotanya.

\section{Fasilitasi Usaha}

Fasilitasi usaha yang dilakukan kelompok dalam hal kerjasama, memberikan informasi, mempromosikan dan memasarkan produk pengolah enbal. Fasilitasi dalam bentuk kerjasama yang dilakukan kelompok yaitu tanggung jawab dalam menyelesaikan suatu tugas dibagi secara merata kepada seluruh anggota kelompok, saling membantu membuka kebun baru, membersihkan lahan, bersepakat memanfaatkan bantuan alat dan mesin pengolahan. Hal tersebut dapat dicermati dari ungkapan UL, seorang ketua kelompok pengolahan sebagai berikut:

"bantuan alat mesin beta simpan saja disini,
beta bilang barang ini kan cok-cokjadi makan
meteran kalau kamorang mau kerja datang
disini saja. Kalau anggota mau kerja pribadi
datang saja pake alat di rumah karena kan
katong punya rekan kerja, seng bayar seng
apa-apa yang penting rajin kerja”.

"bantuan alat mesin beta simpan saja disini, beta bilang barang ini kan cok-cokjadi makan meteran kalau kamorang mau kerja datang disini saja. Kalau anggota mau kerja pribadi datang saja pake alat di rumah karena kan apa-apa yang penting rajin kerja".

Tabel 2. Dukungan Kelompok dalam Meningkatkan Kapasitas Pengolah Enbal di Kabupaten Maluku Tenggara Tahun 2017

\begin{tabular}{ccccc}
\hline No & Dukungan Kelompok & Kategori & Jumlah (Orang) & Persen (\%) \\
\hline 1 & Wadah belajar (Skor) & Rendah $(5-12)$ & 21 & 25,0 \\
& & Tinggi $(13-20)$ & 63 & 75,0 \\
\multirow{2}{*}{2} & \multirow{2}{*}{ Fasilitasi usaha (Skor) } & Rendah $(7-17)$ & 42 & 50,0 \\
& & Tinggi $(18-28)$ & 42 & 50,0 \\
\hline
\end{tabular}


Informasi yang diperoleh anggota terkait jadwal pertemuan dan latihan pengolahan enbal jika diluar waktu yang telah ditetapkan bersama, harga produk enbal di pasar, tempat penjualan kebutuhan pengolah, jenis dan sumber bantuan alat mesin pengolahan yang diterima. Terkait promosi dan pemasaran produk, apabila kelompok mendapat pesanan maka sebagian disiapkan kelompok dan sisanya dibeli dari anggota. Nuryanti dan Swastika (2011) menyatakan bahwa kelompok sangat berperan sebagai wadah kerjasama, unit produksi usaha dan menerapkan hal baru.

\section{Dukungan Penyuluhan dalam Meningkatkan Kapasitas Pengolah Enbal}

Dukungan penyuluhan menunjukkan intensitas penyuluhan berada pada kategori rendah tetapi kesesuaian materi, ketepatan metode, dan kompetensi penyuluh berada pada kategori tinggi (Tabel 3).

\section{Intensitas Penyuluhan}

Kunjungan penyuluhke kelompok pengolahan atau tempat usaha untuk melakukan penyuluhan masih jarang dilakukan. Hal tersebut karena dalam sistem pengembangan enbal penyuluh bertanggung jawab terhadap produksi tanaman enbal sehingga fokus penyuluh saat ini pada aspek budidaya tanaman. Hal tersebut dapat dicermati dari ungkapan UL, ketua kelompok pengolahan sebagai berikut:

"pengolahan lebih banyak dinas ketahanan pangan dan lipi, kalau penyuluh di kebun, padahal cara jual lagi te, bagaimana katong jual, dia pung kendala bagaimana”.
Selain itu, penyuluh belum disiapkan dalam aspek pengolahan. Kegiatan penyuluhan yang sering diikuti pengolah enbal adalah budidaya tanaman karena selain mengolah enbal, pengolah enbal juga memiliki kebun enbal sebagai sumber bahan baku.

\section{Kesesuaian Materi Penyuluhan}

Materi penyuluhan yang diberikan penyuluh menurut pengolah enbal telah beragam, bermanfaat dan mudah dipraktekan. Hal tersebut karena dirasakan sesuai dengan kebutuhan mereka dari aspek budidaya tanaman seperti cara memilih stek enbal, cara menanam, memelihara tanaman, membuat pupuk kompos. Materi-materi tersebut mudah dipraktekan karena telah sering dilakukan, karena dengan tahu dan terampil dalam membudidayakan tanaman enbal maka bahan baku yang mereka butuhkan dalam proses pengolahan akan selalu tersedia namun menurut pengolah materimateri tersebut masih kurang relevan dari aspek pengolahan sehingga mereka berharap penyuluh juga dapat memberikan materi yang terkait pengolahan enbal termasuk bagaimana cara memasarkannya.

\section{Ketepatan Metode Penyuluhan}

Metode yang digunakan penyuluh adalah ceramah, diskusi, dan praktek. Menurut pengolah, mereka lebih mudah memahami materi yang disampaikan penyuluh ketika menggunakan ketiga metode tersebut secara bersamaan (gabungan metode). Hal tersebut karena pengolahmemiliki kesempatanuntuk mendengar, bertanya langsung baik kepada penyuluh maupun sesamateman sekaligus mengerjakannya sendiri

Tabel 3. Dukungan Penyuluhan dalam Meningkatkan Kapasitas Pengolah Enbal di Kabupaten Maluku Tenggara Tahun 2017

\begin{tabular}{|c|c|c|c|c|}
\hline No & Dukungan Penyuluhan & Kategori & $\begin{array}{l}\text { Jumlah } \\
\text { (Orang) }\end{array}$ & $\begin{array}{c}\text { Persen } \\
(\%)\end{array}$ \\
\hline \multirow[t]{2}{*}{1} & Intensitas penyuluhan (Skor) & Rendah $(0-1)$ & 71 & 84,5 \\
\hline & & Tinggi $(2-3)$ & 13 & 15,5 \\
\hline \multirow[t]{2}{*}{2} & Kesesuaian materi penyuluhan (Skor) & Rendah $(0-5)$ & 9 & 10,7 \\
\hline & & Tinggi $(6-10)$ & 75 & 89,3 \\
\hline \multirow[t]{2}{*}{3} & Ketepatan metode penyuluhan (Skor) & Rendah $(0-8)$ & 40 & 47,6 \\
\hline & & Tinggi $(9-16)$ & 44 & 52,4 \\
\hline \multirow[t]{2}{*}{4} & Kompetensi penyuluh (Skor) & Rendah $(0-16)$ & 9 & 10,7 \\
\hline & & Tinggi $(17-33)$ & 75 & 89,3 \\
\hline
\end{tabular}


melalui praktek sehingga lebih membantu mereka untuk memahami materi yang diberikan penyuluh. Misalnya pada saat penyuluh memberikan penjelasan tentang cara memilih stek ubi kayu yang baik, maka penyuluh langsung membawa batangan ubi kayu kemudian setelah memberikan penjelasan, pengolah diberikan kesempatan untuk bertanya selanjutnya penyuluh mempraktekan cara bagaimana memilih stek ubi yang baik menggunakan bahan yang telah disiapkan.

\section{Kompetensi Penyuluh}

Kompetensi penyuluh yaitu kompetensi personal, profesional dan kompetensi sosial. Terkait kompetensi personal, penyuluh dinilai belum mampu membantu menyelesaikan permasalahan pengolah tetapi telah mampu dalam manajemen waktu sehingga mudah dijumpai dan memberikan penjelasan yang mudah dipahami. Kompetensi profesional, penyuluh dinilai belum mampu memberikan informasi yang relevan, belum membantu mendapat bantuan alat dan mesin pengolahan yang sesuai, belum membantu menjalin kerjasama dengan pihak di luar kelompok. Namun penyuluh telah mampu membantu adanya kerjasama dengan instansi/badan pemerintah daerah.

Kompetensi sosial, penyuluh telah mampu membina hubungan baik dengan anggota kelompok, dipercaya, dan mampu mengendalikan diri dengan cara sabar dalam memberikan penjelasan saat dibutuhkan. Hal tersebut tidak terlepas dari pengalaman tugas penyuluh. Hal tersebut dapat dicermati dari ungkapan MS, seorang bendahara kelompok pengolahan sebagai berikut:

\section{"Bapak NM itu paling baik, katong perlu apa- apa itu telpon saja antua su datang, antua paling sering datang di rumah sini deng paitua. Kalau katong jadwal kerja di kebun antua datang, antua bantu bawa alat untuk garu tanah, jadi bagus skali"}

Hal tersebut sejalan Marliati et al., (2008) yang menyatakan bahwa kompetensi berkomunikasi, kompetensi membelajarkan petani, dan kompetensi berinteraksi sosial sangat membantu keberhasilan tugas penyuluh.

\section{Dukungan Ketersediaan Fasilitas Usaha dalam Meningkatkan Kapasitas Pengolah Enbal}

Dukungan ketersediaan fasilitas usaha menunjukkan bahwa ketersediaan modal berada pada kategori rendah tetapi ketersediaan sarana prasarana pengolahan berada pada kategori mudah dan murah (Tabel 4).

\section{Ketersediaan Modal}

Rendahnya dukungan ketersediaan modal karena pengolah enbal sulit melakukan pinjaman pada lembaga keuangan formal terutama bank. Hal tersebut karena persyaratan yang harus dipenuhi dan proses pengurusan berulang yang merepotkan mereka sehingga ada yang pernah meminjam tetapi terbatas pada satu sumber modal dan bahkan ada yang tidak meminjam. Kondisi tersebut menyebabkan mereka lebih memilih menggunakan modal sendiri meskipun terbatas. Hal tersebut dapat dicermati dari ungkapan TK, sekretaris kelompok pengolahan sebagai berikut:

"modal usaha seng ada dari mana-mana ne
modal sendiri saja karena takut yang begitu,
katong penghasilan seng menentu ne dimana
pasar panas ya bagus tapi kadang seng, jadi
mama tidak berani begitu”.

Meskipun demikian, terdapat 14,3 persen pengolah yang pernah mendapat pinjaman modal dari beberapa lembaga keuangan terutama koperasi kredit/ CU, koperasi simpan pinjam, dan badan usaha milik desa. Fausiah (2016) menyatakan bahwa umumnya modal usaha pengolah pangan berasal dari modal sendiri dan sangat terbatas dalam mengembangkan usaha.

\section{Ketersediaan Sarana Prasarana Pengolahan}

Sarana dan prasarana pengolahan tersedia sehingga mudah diperoleh dan murah sehingga dapat dibeli. Hal tersebut karena terdapat beberapa tempat penjualan seperti pasar tradisional, supermarket GOTA, toko alat mesin menyediakan kebutuhan pengolah seperti alat dan mesin pengolahan, bahan tambahan pangan (keju, coklat dan lainnya), kemasan standar disediakan LIPI, cetakan dipesan di STM Langgur. Mesin pengolahan yang memiliki harga antara Rp. 1.300.000,- hingga Rp. 3.600.000,- masih cukup mahal bagi pengolah, tergantung pada merek mesin yang akan dibeli.

Sarana yang dibutuhkan pengolah enbal dalam kegiatan produksi terdiri dari peralatan, mesin dan bahan. Beberapa jenis alat yang digunakan dalam 
Tabel 4. Dukungan Ketersediaan Fasilitas Usaha dalam Meningkatkan Kapasitas Pengolah Enbal di Kabupaten Maluku Tenggara tahun 2017

\begin{tabular}{cllcc}
\hline No & \multicolumn{1}{c}{ Fasilitas usaha } & \multicolumn{1}{c}{ Kategori } & Jumlah (Orang) & Persen (\%) \\
\hline 1 & Ketersediaan modal & Rendah $(0-4)$ & 72 & 85,7 \\
& (Skor) & Tinggi $(5-9)$ & 12 & 14,3 \\
2 & Ketersediaan sarana prasarana & Mudah, Murah & 66 & 78,6 \\
& pengolahan (Skor) & $(35-40)$ & & \\
& & Sangat mudah, sangat murah & 18 & 21,4 \\
& & $(41-46)$ & & \\
\hline
\end{tabular}

proses pengolahan enbal adalah loyang, ayakan, nyiru, wajan, aneka cetakan, kompor, molen, kemasan. Mesin yang digunakan adalah mesin parut, mesin pengepres, dan mesin penepung. Bahan yang digunakan adalah enbal gepe, bahan tambahan pangan seperti gula, keju, coklat, mentega, tersedia dengan mudah sehingga sangat mendukung aktifitas pengolahan. Prasarana seperti jalan yang menghubungkan desa/ohoi dengan pasar serta Kota Langgur sebagai ibu kota kabupaten memiliki kualitas yang baik. Hal ini memberikan kemudahkan bagi aktivitas pengolah dari dan ke pasar baik untuk memasarkan hasil olahan maupun untuk membeli alat dan bahan yang dibutuhkan. Fasilitas penerangan berupa listrik telah dinikmati oleh seluruh pengolah enbal sebagai alat penerangan utama dan sebagian telah menggunakan air bersih yang bersumber dari Perusahaan Air Minum (PAM). Hal tersebut dapat dicermati dari ungkapan $\mathrm{MO}$, seorang ketua kelompok pengolahan sebagai berikut:

"sekarang ini GOTA su ada jadi katong belanja apa-apa di sana saja, mau coklat ka keju semua su ada, kalau nyiru lain-lain itu di pasar langgur, cetakan katong pesan di STM, air PAM juga sudah masuk.. jadi gampang tinggal tanya uang saja"

\section{Dukungan Pasar dalam Meningkatkan Kapasitas Pengolah Enbal}

Dukungan pasar menunjukkan tempat penjualan berada padakategori rendah tetapi kesesuaian harga, ketersediaan informasi pasar, dan permintaan produk berada pada kategori tinggi (Tabel 5).

\section{Kesesuaian Harga}

Harga olahan di pasar saat ini tinggi dan harga jenis olahan aneka rasa lebih mahal dari yang bukan aneka rasa. Harga olahan tersebut menurut pengolah telah sesuai dengan harga yang diharapkannya. Hal tersebut karena pengolah juga menentukan harga dengan mempertimbangkan harga jual di pasar untuk menghindari perbedaan yang jauh antara harga pengolah dan pedagang. Hal tersebut dapat dicermati dari ungkapan DO, seorang sekretaris kelompok pengolahan sebagai berikut:

"harga olahan ini katong tentukan sendiri,
pemerintah seng tentukan karena katong yang
tau katong pake apa saja untuk buat olahan
jadi katong yang tau musti jual berapa baru
untung"

\section{Informasi Pasar}

Pengolah enbal mengetahui dengan baik informasi terkait harga setiap olahan enbal dan jenis olahan yang disukai pembeli. Informasi tersebut diperoleh secara langsung dari aktivitasnya di pasar pada saat menjual produk serta hasil komunikasi antar sesama pengolah baik di luar maupun dalam kelompok. Hal tersebut menunjukkan bahwa informasi tersebut tersedia dan mudah diperoleh. Namun, ada beberapa informasi yang belum diketahui pengolah seperti cara menjual olahan pada pusat penjualan dan cara promosi pada media lokal.

Hal tersebut dapat dicermati dari ungkapan $\mathrm{MN}$, seorang bendahara kelompok pengolahan sebagai berikut:

\footnotetext{
"enbal apa yang orang suka itu katong cepat dapa tau karena tanya-tanya to begitu juga harga, cuma kalau cara bagaimana supaya bisa jual di GOTA atau kasi keluar di koran ka lewat radio itu katong belum pernah buat
} 
Tabel 5. Dukungan Pasar dalam Meningkatkan Kapasitas Pengolah Enbal di Kabupaten Maluku Tenggara Tahun 2017

\begin{tabular}{cllcc}
\hline No & \multicolumn{1}{c}{ Dukungan pasar } & \multicolumn{1}{c}{ Kategori } & Jumlah (Orang) & Persen (\%) \\
\hline 1 & Kesesuaian harga & Rendah $(0-3)$ & 20 & 23,8 \\
& (Skor) & Tinggi $(4-6)$ & 64 & 76,2 \\
2 & Informasi pasar & Rendah $(0-3)$ & 24 & 28,6 \\
& (Skor) & Tinggi $(4-6)$ & 60 & 71,4 \\
3 & Permintaan produk (Skor) & Rendah $(0-1)$ & 28 & 33,3 \\
& & Tinggi $(2-3)$ & 56 & 66,7 \\
4 & Tempat penjualan & Rendah $(<2)$ & 76 & 90,5 \\
& (Rataan =1) & Tinggi $(\geq 2)$ & 8 & 9,5 \\
\hline
\end{tabular}

trus seng ada yang kasi tau jadi katong seng tau"

\section{Permintaan Produk}

Tingginya permintaan produk karena hasil penjualan olahan enbal di pasar selalu habis terjual dan hanya sedikit yang tersisa. Permintaan olahan enbal baik yang aneka rasa maupun bukan aneka rasa karena selain untuk memenuhi kebutuhan konsumsi menggantikan roti/nasi, oleh-oleh juga cemilan juga untuk mengirim anak atau saudara yang berada di rantau. Hal tersebut dapat dicermati dari ungkapan TK, seorang sekretaris kelompok pengolahan sebagai berikut:

"orang yang beli enbal ini bukan dari kota saja, orang dari kampung-kampung lai. Apalagi hujan-hujan bagini sapa yang barani asar enbal ... seng ada. Jadi ini bukan orang dari kota yang datang cari enbal saja orang dari kampung juga yang datang cari enbal. Dong mau kirim-kirim dong keluarga, dong makan, dong apa dong beli saja. Kebetulan kapal jadi mungkin dong mau kirim. Kapal kemarin ke Timika ka jadi dong cari enbal. Ipar tadi cerita kata dong tiga orang $k a$ empat orang saja bajual di pasar lalu dong satu orang bawa dua ka tiga tas habis samua akhirnya dong bale datang ambil yang masih ada di rumah bawa pi samua habis"

Beberapa jenis enbal yang disukai pembeli adalah enbal bunga, enbal plat tawar, stik enbal dan stik mocaf. Selain itu, penggunaan kemasan standar dengan label informatif (tertera nomor kontak/HP) memudahkan pembeli untuk mendapatkan produk baik membeli langsung maupun memesan.

\section{Tempat Penjualan}

Rata-rata pengolah hanya memiliki satu tempat penjualan sebagai sumber pesanan yaitu perorangan. Mereka adalah orang-orang yang selalu memanfaatkan enbal untuk berbagai tujuan seperti untuk konsumsi sebagai wujud kebanggaan mereka terhadap pangan lokal. Hal tersebut dapat dicermati dari ungkapan $\mathrm{MN}$, seorang bendahara kelompok pengolahan sebagai berikut:

"kalau orang perlu lalu enbal gepe seng ada beta ke pasar beli, apalagi langganan kan seng mungkin kasi kecewa dong. Tapi kalau seng ada gepe yang baik lagi satu-satunya jalan ambil anggota lain punya yang su ada.

Tempat-tempat penjualan utama seperti toko oleh-oleh Arab Tual dan Gota Supermarket belum mendukung penjualan karena terkait harga produk yang tidak sesuai dan belum ada hubungan kerjasama/ langganan.

\section{Faktor-faktor yang Mempengaruhi Kapasitas Pengolah Enbal}

Analisis PLS melalui iterasi algoritma menghasilkan parameter pengujian model pengukuran berupa Average Varian Extracted (AVE) >0,5, discriminant validity, dan composite reliability $>0,7$ (Tabel 6) dan nilai faktor loading $>0,7$ (Tabel 7) yang 
Tabel 6. Parameter Pengujian Model Pengukuran Indikator Faktor-Faktor yang Mempengaruhi Kapasitas Pengolah Enbal di Kabupaten Maluku Tenggara Tahun 2017

\begin{tabular}{clccc}
\hline No & \multicolumn{1}{c}{ Peubah Laten } & $\begin{array}{c}\text { Average Varian } \\
\text { Extracted }\end{array}$ & $\begin{array}{c}\text { Discriminant } \\
\text { Validity }\end{array}$ & Composite Reliability \\
\hline 1 & Karakteristik internal & 0.774 & 0,863 & 0.853 \\
2 & Dukungan kelompok & 0.891 & 0,944 & 0.942 \\
3 & Dukungan penyuluhan & 0.850 & 0.922 & 0.944 \\
4 & Ketersediaan fasilitas usaha & 1.000 & 1.000 & 1.000 \\
5 & Dukungan pasar & 0.812 & 0.901 & 0.945 \\
\hline
\end{tabular}

menunjukkan bahwa indikator telah valid dan reliabel karena dapat merefleksikan peubah laten.

Analisis PLS melalui proses bootstraping menghasilkan parameter pengujian model struktural (inner model) yang menunjukkan signifikansi pengaruh masing-masing peubah laten eksogen terhadap peubah laten endogen (Tabel 7).

Hasil evaluasi model struktural menunjukkan faktor-faktor yang berpengaruh terhadap kapasitas pengolah enbal di Kabupaten Maluku Tenggara terdiri atas faktor internal dan eksternal. Faktor internal adalah keaktifan dalam kelompok dan motivasi mengembangkan usaha. Faktor eksternal adalah dukungan kelompok, dukungan penyuluhan, ketersediaan fasilitas usaha, dukungan pasar. Nilai $\mathrm{R}^{2}$ sebesar 0.865 menunjukkan bahwa 86.5 persen kapasitas pengolah enbal dipengaruhi oleh faktorfaktor yang diteliti dalam penelitian ini sedangkan 13,5 persen dipengaruhi oleh faktor lain diluar penelitian ini dan karena nilainya diatas 0.75 maka model yang dihasilkan termasuk kategori kuat untuk memprediksi peningkatan kapasitas pengolah enbal (Gambar 1).

Karakteristik internal pengolah enbal yang direfleksikan oleh indikator keaktifan dalam kelompok dan motivasi mengembangkan usaha berpengaruh terhadap kapasitas pengolah enbal sebesar 0,15 dengan nilai t-statistik sebesar 2,43 lebih besar dari nilai t-tabel 1,64 . Artinya bahwa terdapat pengaruh positif dan langsung yang signifikan karakteristik internal pengolah enbal terhadap kapasitas pengolah enbal. Semakin tinggi karakteristik internal pengolah enbal (keaktifan dalam kelompok dan motivasi mengembangkan usaha) maka semakin tinggi pula kapasitas pengolah enbal. Pengolah enbal yang aktif dalam kegiatan kelompok dan memiliki motivasi dalam mengembangkan usaha berpengaruh secara langsung terhadap peningkatan kapasitasnya dalam aspek teknis pengolahan, strategi pasar, dan akses modal usaha.
Kehadiran anggota kelompok pada setiap kegiatan karena kelompok telah memiliki jadwal kegiatan yang disepakati secara bersama dan diketahui oleh semua anggota. Anggota yang hadir akan dilibatkan secara langsung dalam kegiatan kelompok yang direncanakan pada saat itu.

Dukungan kelompok yang direfleksikan oleh indikator wadah belajar dan fasilitasi usaha berpengaruh terhadap kapasitas pengolah enbal sebesar 0,15 dengan nilai t-statistik 2,89 lebih besar dari nilai t-tabel 1,64. Artinya bahwa terdapat pengaruh positif dan langsung yang signifikan dukungan kelompok terhadap kapasitas pengolah enbal. Semakin tinggi dukungan kelompok maka semakin tinggi pula kapasitas pengolah enbal.

Sebagai wadah belajar, kelompok membantu pengolah enbal untuk meningkatkan kemmapuannya melalui keikutsertaan anggota pada kegiatan belajar bersama yang dilakukan untuk mendapat pengetahuan dan keterampilan baru tentang pengolahan enbal. Kegiatan belajar dapat diikuti anggota baik di dalam maupun luar kelompok. Belajar di luar kelompok adalah proses belajar yang dilakukan anggota karena ditunjuk mewakili kelompok untuk mengikuti kegiatan baik berupa pelatihan, sosialisasi atau pertemuan yang diselenggarakan oleh pihak lain seperti dinas/badan pemerintah. Dukungan kelompok dalam meningkatkan kapasitas pengolah enbal melalui fasilitasi usaha dilakukan dengan mengembangkan kerjasama antar sesama anggota kelompok, berbagi informasi, mendapat dan memanfaatkan bantuan alat mesin pengolahan, memperlancar promosi dan pemasaran produk serta pada sebagian kelompok terdapat rumah produksi yang dapat dimanfaatkan anggota untuk melakukan pengolahan.

Dukungan penyuluhan yang direfleksikan oleh indikator kesesuaian materi, ketepatan metode, dan kompetensi penyuluh berpengaruh terhadap kapasitas pengolah enbal sebesar 0,07 dengan nilai t-statistik 
Tabel 7. Parameter Pengujian Model Struktural Faktor-Faktor yang Mempengaruhi Kapasitas Pengolah Enbal di Kabupaten Maluku Tenggara Tahun 2017

\begin{tabular}{clcc}
\hline No & \multicolumn{1}{c}{ Matriks } & Original sample & T statistics \\
\hline 1 & Karakteristik internal => kapasitas & 0,145 & 2,458 \\
2 & Karakteristik internal => keberlanjutan & 0,474 & 3,152 \\
3 & Dukungan kelompok => kapasitas & 0,148 & 2,892 \\
4 & Dukungan kelompok => keberlanjutan & $-0,490$ & 3,659 \\
5 & Dukungan penyuluhan => kapasitas & 0,076 & 1,945 \\
6 & Dukungan penyuluhan => keberlanjutan & 0,363 & 3,366 \\
7 & Ketersediaan fasilitas usaha => kapasitas & 0,288 & 4,923 \\
8 & Ketersediaan fasilitas usaha => keberlanjutan & $-0,047$ & 0,389 \\
9 & Dukungan pasar => kapasitas & 0,583 & 12,864 \\
10 & Dukungan pasar => keberlanjutan & $-0,425$ & 2,705 \\
\hline
\end{tabular}

1,95 lebih besar dari nilai t-tabel 1,64. Artinya bahwa terdapat pengaruh positif dan langsung yang signifikan dukungan penyuluhan terhadap kapasitas pengolah enbal. Semakin tinggi dukungan penyuluhan maka semakin tinggi pula kapasitas pengolah enbal.

Penyuluh pertanian yang memiliki kompetensi baik personal, profesional maupun sosial yang memadai akan mampu memberikan materi yang sesuai dengan kebutuhan pengolah enbal menggunakan metode penyuluhan yang tepat. Beberapa kompetensi penyuluh yang telah dilakukan dengan baik seperti membantu adanya kerjasama dengan instansi/badan pemerintah daerah, mampu manajemen waktu sehingga mudah dijumpai oleh pengolah enbal juga didukung oleh pemilikan alat komunikasi, mampu memberikan penjelasan yang mudah dipahami oleh pengolah karena penggunaan kata-kata yang sudah sering digunakan oleh pengolah dalam kesehariannya, memfasilitasi kerjasama pengolah dengan dinas/ badan pemerintah berupa keterlibatan pengolah dalam kelompok-kelompok pengolahan untuk membantu menyukseskan program dan kegiatan dinas/badan seperti pengembangan tanaman enbal oleh dinas pertanian.

Meskipun saat ini fokus penyuluh masih pada aspek budidaya tanaman tetapi telah mampu meningkatkan kemampuan pengolah enbal dalam membudidayakan tanaman enbal sehingga kebutuhan bahan baku dalam proses produksi olahan enbal akan senantiasa tersedia. Hasil penelitian ini sejalan dengan Asta at el., (2015) yang menyatakan bahwa interaksi yang terjadi antara penyuluh dan petani dalam kegiatan penyuluhan mampu meningkatkan kapasitas petani dalam pengelolaan usaha.

Dukungan ketersediaan fasilitas usaha yang direfleksikan oleh indikator ketersediaan modal berpengaruh terhadap terhadap kapasitas pengolah enbal sebesar 0,29 dengan nilai t-statistik 4,92 lebih besar dari nilai t-tabel 1,64 . Artinya bahwa terdapat pengaruh positif dan langsung yang signifikan dukungan ketersediaan fasilitas usaha terhadap kapasitas pengolah enbal. Semakin tinggi dukungan ketersediaan fasilitas usaha maka semakin tinggi pula kapasitas pengolah enbal. Ketersediaan modal usaha pada lembaga keuangan formal berupa berbagai jenis fasilitas kredit yang dapat diakses oleh pengolah enbal seperti KUR perlu diinformasikan secara jelas dan terbuka terkait persyaratan dan prosedur pengurusannya sehingga memudahkan bagi mereka dan terdorong untuk mau memanfaatkan fasilitas-fasilitas kredit pada lembaga keuangan formal. Kemudahan untuk dapat mengakses modal usaha dengan memanfaatkan fasilitas kredit akan meningkatkan kapasitas pengolah enbal baik dalam teknis pengolahan, strategi pasar, maupun akses modal usaha karena modal tersedia dalam jumlah yang cukup untuk memenuhi kebutuhan usaha.

Pada teknis pengolahan, pengolah enbal akan mampu membeli kemasan yang standar untuk mengemas produk yang dihasilkan, menggunakan bahan tambahan pangan secara kontinyu, mengurus legalitas produk seperti PIRT dan kedaluwarsa produk sehingga dapat menggunakan label yang lebih menarik dengan informasi produk yang lengkap. Pengolah juga akan mampu melakukan strategi pasar dengan memanfaatkan media-media lokal untuk promosi 


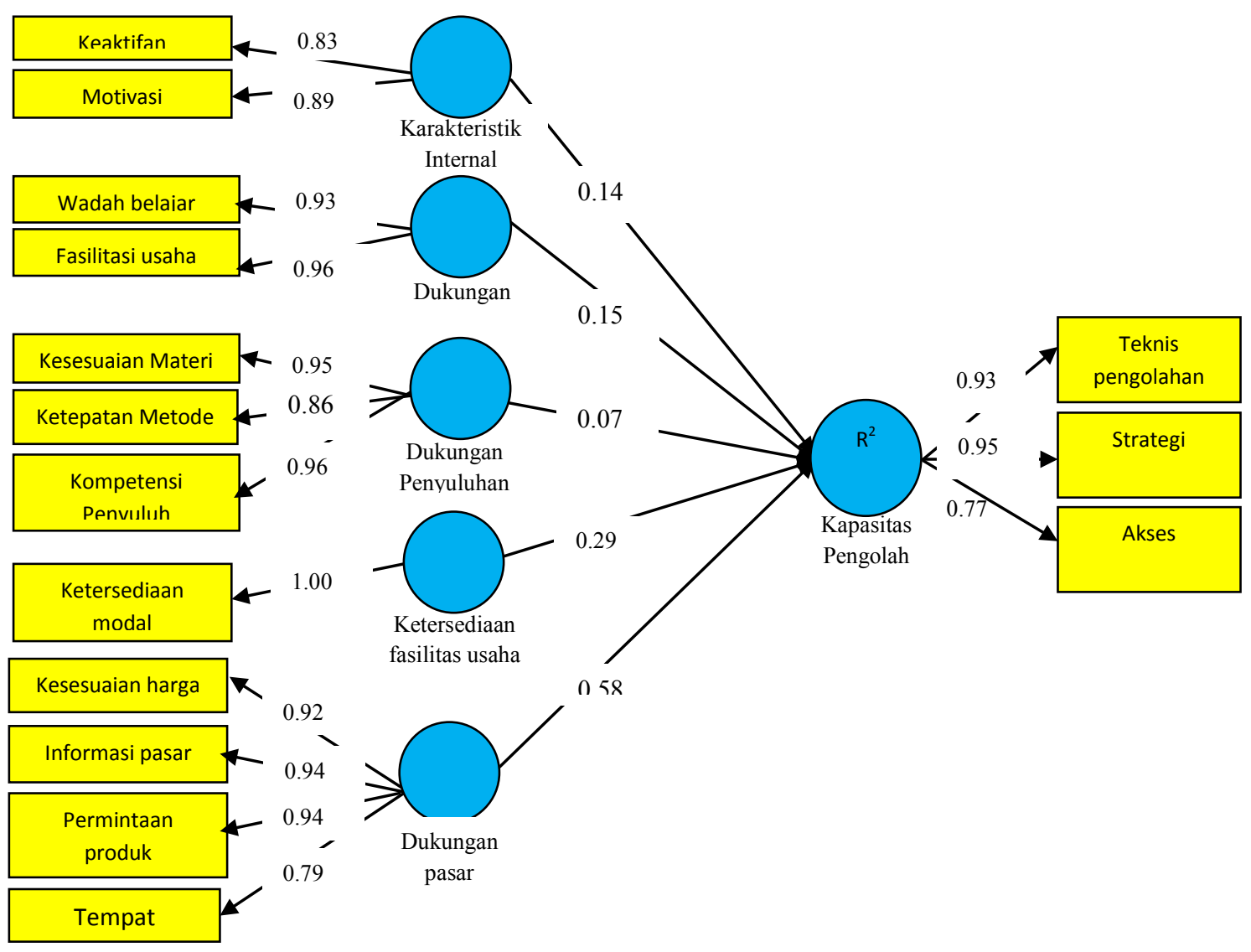

Gambar 1. Model pengukuran faktor-faktor yang mempengaruhi kapasitas pengolah enbal

produk yang dihasilkan dan melakukan penjualan produk ke pusat-pusat penjualan karena kualitas produk secara keseluruhan telah memenuhi syarat untuk dijual pada tempat-tempat tersebut. Pengolah enbal juga mau membiasakan diri untuk mulai mengakses modal usaha pada lembaga keuangan formal baik dalam memenuhi persyaratan pinjaman, penggunaan pinjaman sesuai tujuan peminjaman maupun mengembalikan pinjaman secara tepat waktu.

Dukungan pasar yang direfleksikan oleh indikator kesesuaian harga, informasi pasar, permintaan produk dan tempat penjualan berpengaruh terhadap kapasitas pengolah enbal sebesar 0,58 dengan nilai t-statistik 12,86 lebih besar dari nilai t-tabel 1,64. Artinya bahwa terdapat pengaruh positif dan langsung yang signifikan dukungan pasar terhadap kapasitas pengolah enbal. Semakin tinggi dukungan pasar maka semakin tinggi pula kapasitas pengolah enbal.

Kesesuaian harga olahan di pasar dilihat dari harga produk dan perbandingan harga antara jenis aneka rasa dan bukan aneka rasa. Harga produk di pasar saat ini tinggi artinya bahwa telah sesuai dengan harapan pengolah enbal. Hal tersebut karena penetapan harga olahan enbal dilakukan sendiri oleh pengolah dengan mempertimbangkan harga olahan yang beredar di pasar dan toko oleh-oleh. Harga olahan enbal aneka rasa juga lebih tinggi dibandingkan olahan yang bukan aneka rasa.

Hal tersebut disebabkan untuk menghasilkan enbal aneka rasa pengolah mengeluarkan sejumlah biaya untuk membeli bahan tambahan pangan. Aktivitas pengolah enbal dalam memproduksi maupun memasarkan produk baik di rumah maupun pasar menyebabkan pengolah enbal mengetahui informasi terkait harga dan jenis olahan enbal yang disukai oleh pembeli.

Pengetahuan tentang kedua informasi tersebut menyebabkan pengolah selalu termotivasi untuk meningkatkan kapasitasnya melalui proses belajar baik di dalam maupun luar kelompok. Disisi lain, saat ini belum banyak produk olahan pangan lokal yang dipasarkan ke GOTA Supermarket. Hal tersebut merupakan peluang bagi pengolah enbal untuk meningkatkan omset usaha dengan menghasilkan produk yang dapat dijual oleh pihak GOTA. Hasil penjualan olahan enbal termasuk dalam kategori tinggi karena olahan selalu habis terjual dan hanya sedikit yang tersisa. Suryani et al.,(2017) menyatakan bahwa 
dukungan aspek pemasaran sangat penting bagi usaha rumah tangga.

\section{Pengaruh Kapasitas terhadap Keberlanjutan Usaha Pengolahan Enbal}

Kapasitas pengolah enbal yang direfleksikan oleh indikator teknis pengolahan, strategi pasar dan akses modal usaha berpengaruh terhadap keberlanjutan usaha pengolahan enbal sebesar 0,83 dengan nilai t-statisik 3,48 lebih besar dari nilai t-tabel 1,64. Artinya bahwa terdapat pengaruh positif dan langsung yang signifikan kapasitas pengolah enbal terhadap keberlanjutan usaha pengolahan enbal. Semakin tinggi kapasitas pengolah enbal maka semakin tinggi pula keberlanjutan usaha pengolahan enbal (Gambar 1).

Beberapa hal terkait aspek teknis pengolahan yang telah dilakukan pengolah enbal dengan baik misalnya selalu menyediakan bahan baku sendiri, menggunakan air bersih pada semua tahap pengolahan, mengeringkan enbal olahan dengan cara yang lebih baik seperti melakukan pengasapan, penjemuran dan pemanggangan memberikan tingkat kekeringan yang baik terhadap produk olahan. Hal tersebut akan menjamin kelangsungan usaha pengolahan enbal pada aspek produksi, omset dan keuntungan usaha. Menyediakan enbal gepe yang dilakukan secara langsung merupakan bentuk komitmen pengolah enbal untuk selalu menjaga dan menggunakan bahan baku dengan kualitas yang baik. Kualitas bahan baku yang baik akan menghasilkan produk olahan yang baik karena akan menarik dari sisi warna dan rasa. Rasa hasil olahan yang tidak sesuai karena salah menggunakan bahan baku akan berdampak buruk pada usaha karena pembeli tidak akan membeli hasil olahan yang memiliki rasa asam begitu pula dengan langganan.

Dalam aspek strategi pasar, kemampuan pengolah enbal untuk menghasilkan empat sampai enam produk, memberikan potongan harga dan memberikan persenan/tambahan akan menjamin kelangsungan usaha pengolahan enbal. Jumlah produk yang dihasilkan lebih banyak akan memberikan pilihan kepada pembeli untuk membeli produk olahan sesuai selera sehingga akan menarik minat pembeli untuk selalu membeli. Memberikan potongan harga atau memberikan persenan/tambahan beberapa bungkus produk pada pembeli yang membeli dalam nilai pembelian tertentu seperti diatas Rp. 50.000,merupakan cara yang digunakan pengolah untuk menarik simpati pembeli dan memberikan peluang untuk menjalin kerjasama sebagai langganan karena semakin banyak langganan yang dimiliki pengolah enbal maka akan semakin baik bagi kelangsungan usahanya karena ada jaminan pemasaran bagi produk yang dihasilkan.

Akses modal usaha pada lembaga keuangan formal merupakan aspek kemampuan pengolah enbal yang memiliki nilai loading factor yang rendah jika dibandingkan dengan dua aspek sebelumnya. Hal tersebut menunjukkan bahwa agar usaha pengolahan enbal dapat berlangsung dengan baik maka pengolah enbal harus meningkatkan kemampuannya untuk mengakses modal usaha pada lembaga keuangan formal. Meskipun berpengaruh positif langsung terhadap keberlanjutan usaha namun modal yang digunakan saat ini masih terbatas pada modal sendiri sehingga belum dapat diandalkan sepenuhnya untuk mempertahankan kelangsungan usaha dengan melakukan pengembangan usaha karena modal hanya digunakan untuk membeli kebutuhan yang terkait langsung dengan proses produksi.

Beberapa hal yang perlu diperhatikan juga oleh pengolah enbal agar usaha pengolahan enbal dapat berkembang dan tetap dapat dipertahankan kelangsungannya yaitu menggunakan kemasan yang standar, menambah jenis dan jumlah produk, dan mulai melakukan hal-hal yang terkait dengan strategi pasar seperti promosi pada media lokal dan mengikuti pameran. Penggunaan kemasan yang standar akan menjamin kualitas produk dan memperlama masa simpan produk terutama enbal aneka rasa yang memiliki waktu penyimpanan singkat juga memudahkan pengolah enbal untuk memberikan label pada kemasan produk yang dapat memberikan terkait produk. Produk yang memiliki label dengan informasi yang lengkap akan menarik bagi pembeli dan memberikan peluang untuk dijual pada pusat perbelanjaan seperti GOTA Supermarket sehingga dapat menambah omset usaha. Kemasan produk yang baik juga akan memudahkan dilakukannya promosi terutama pada saat mengikuti pameran baik di dalam maupun luar daerah.

\section{Kesimpulan}

Kapasitas pengolah enbal di Kabupaten Maluku Tenggara masih terbatas dalam hal: strategi pasar dan akses modal usaha tetapi relatif lebih baik pada teknis pengolahan. Strategi pasar yang belum dilakukan dengan baik oleh pengolah enbal adalah pemberian potongan harga produk, melakukan promosi pada media lokal, mengikuti pameran, penjualan olahan 
ke pusat oleh-oleh dan pusat penjualan. Pengolah enbal juga belum mampu memenuhi persyaratan pinjaman, mengembalikan pinjaman tepat waktu, dan memanfaatkan pinjaman sesuai tujuan pada aspek akses modal sedangkan pada teknis pengolahan adalah produksi produk yang menggunakan bahan tambahan pangan (coklat, keju), penggunaan jenis kemasan yang standar dengan label produk memiliki informasi lengkap dan jumlah produk yang telah memiliki nomor pangan industri rumah tangga.

Tingkat kapasitas pengolah enbal dipengaruhi oleh faktor internal dan eksternal. Faktor yang dominan berpengaruh terhadap kapasitas pengolah enbal adalah dukungan pasar meliputi kesesuaian harga, ketersediaan informasi, permintaan produk, tempat penjualan selanjutnya adalah ketersediaan fasilitas usaha berupa ketersediaan modal, dukungan kelompok sebagai wadah belajar dan fasilitasi usaha, karakteristik internal berupa keaktifan dalam kelompok dan motivasi mengembangkan usaha, dan dukungan penyuluhan berupa kesesuaian materi, ketepatan metode, dan kompetensi penyuluh. Kapasitas pengolah enbal berupa teknis pengolahan, strategi pasar dan akses modal usaha berpengaruh terhadap keberlanjutan usaha pengolahan enbal di Kabupaten Maluku Tenggara.

\section{Daftar Pustaka}

Anantanyu S. 2011. Kelembagaan Petani: Peran dan Strategi Pengembangan Kapasitasnya. Jurnal SEPA. 7(2): 102-109.

Asta DU, Hubeis AVS, Fatchiya A. 2015. Kapasitas Petani Kakao Bekas Penambang Batu Bara di Kota Sawahlunto Sumatera Barat. Jurnal Penyuluhan. 11(2):1-16.

Hadad MD, Maftuchah I. 2015. Sustainable Financing; Industri Jasa Keuangan dalam Pembiayaan Berkelanjutan. Jakarta (ID): Elex Media Komputindo.

Mikro Makanan Ringan tentang Mutu Produk di Cilegon dan Pandeglang Provinsi Banten. Jurnal Penyuluhan. 12 (2): 168-182.

Fausiah S. 2016. Efektivitas Pembinaan Usaha Industri

Kecil Olahan Pangan Oleh Dinas Koperasi UMKM Perindustrian dan Perdagangan Kabupaten Sigi (Studi di Kecamatan Sigi Biromaru). Jurnal Katalogis. 4(1): 68-81.

Hartati. 2016. Ubi Kayu, Makanan Si Miskin yang Kaya Nutrisi. Jurnal Biotrends. 7(1): 48-52.

Havighurst RJ. 1974. Developmental Tasks and
Education. Third Edition. New York (NY): David McKay Company Inc.

Herman S, Sumardjo, Asngari PS, Tjitropranoto P, Susanto D. 2008. Kapasitas Petani Dalam Mewujudkan Keberhasilan Usaha Pertanian: Kasus Petani Sayuran di Kabupaten pasuruan dan Kabupaten Malang Provinsi Jawa Timur. Jurnal Penyuluhan. 4(1): 11-20

Hikmah, Yulisti M, Nasution Z. 2011. Analisis Indeks dan Status Keberlanjutan Peran Serta Wanita Dalam Pengembangan UsahaPengolahan Hasil Perikanan. Jurnal Sosek KP. 6(1):103-114.

Ibrahim H, Amanah S, Gani DS, Purnaningsih N. 2013. Analisis Keberlanjutan Usaha Pengrajin Ekonomi Kreatif Kerajinan Sutera di Provinsi Sulawesi Selatan. Jurnal Telnologi Industri Pertanian. 23(3):210-219.

Indariawati P, Raharja S, Soekarto ST. 2011. Kajian Strategi Pengembangan Usaha Industri Kripik Singkong Perusahaan PT. Inti Sari Rasa di Bekasi. Jurnal Manajamen IKM. 8(2): 99-104.

Liou J. 2004. Community Capacity Building to Strengthen Socio-Economic Development with Spatial Asset Mapping. 3rd FIG Regional Conference. Jakarta (ID).1-10.

Marliati, Sumardjo, Asngari PS, Tjitropranoto P, Saefuddin A. 2008. Faktor-Faktor Penentu Kinerja Penyuluh Pertanian Dalam Memberdayakan Petani. Jurnal Penyuluhan. 4(2): 92-99.

Miftakhuljanah O, Priatna WB, Suharno. 2016. Peran Wanita Pada industri Kecil Kerupuk Kemplang di Kabupaten Ogan Ilir. Jurnal Manajemen dan Agribisnis. 13(2): 122-131.

Milen A. 2001. What Do We Know about Capacity Building. An Overview of Existing Knowladge and Good Practice. Geneva.

Muhibudin, Amanah S, Sadono D. 2015. Tingkat Kompetensi Petani Agribisnis Sayuran Lahan Sempit di Kota Banda Aceh dan Kabupaten Aceh Besar. Jurnal Penyuluhan. 11(2): 186-200.

Nuryanti S, Swastika DKS. 2011. Peran kelompok Tani Dalam Penerapan Teknologi Pertanian. Jurnal Forum Penelitian Agroekonomi Pertanian. 29(2): 115-128.

Pakpahan HT, Lumintang RWE, Susanto D. 2006. Hubungan Motivasi Kerja Dengan Perilaku Nelayan Pada Usaha Perikanan Tangkap. Jurnal Penyuluhan. 2(1): 1-9.

Reijntjes C, Havekort B, Bayer AW. 1999. Pertanian Masa Depan, Pengantar untuk Pertanian Berkelanjutan dengan Input Luar Rendah. Fliert 
van de E, Hidayat B, editor. Yogyakarta (ID): Kanisius.

Riry J, Lawalata VN, Tapotubun EJ, Far-far R. 2013. Mutu Organoleptik Produk Enbal Fortifikasi Ditinjau Dari Daya Terima Konsumen. JPHPI. 16(3): 159-267.

Sapar, Lumintang WE, Susanto D. 2006. Faktor-Faktor yang Berkaitan dengan Perilaku Kewirausahaan Pedagang Kaki Lima (Kasus Pedagang Kaki Lima Pemakai Gerobak Usaha Makanan Di Kota Bogor). Jurnal Penyuluhan. 2(2): 62-68.

Suryani A, Fatchiya A, Susanto D. 2017. Keberlanjutan Penerapan Teknologi Pengelolaan Pekarangan oleh Wanita Tani di Kabupaten Kuningan. Jurnal Penyuluhan. 13(1): 50-63.

[UNDP] United Nations Development Programme. 1998.Capacity Assessment And Development; In a Systems andStrategic Management Context. Technical Advisory Paper 3.

Wibowo CT, Sumardjo, Hafifuddin D, Agung SS. 2012. Pola Komunikasi pada Pengembangan Kapasitas Kewirausahaan Petani Sayuran. Jurnal Komunikasi Pembangunan. 10(1): 47-57. 